Rutkiewicz K., State aid for research, development and innovation in the European Union competition policy, „Ekonomia i Prawo. Economics and Law.”, Polszakiewicz B., Boehlke J. (ed.), Vol. 14, No. 1/2015, pp. 19-32. DOI: http://dx.doi.org/10.12775/EiP.2015.002.

\title{
STATE AID FOR RESEARCH, DEVELOPMENT AND INNOVATION IN THE EUROPEAN UNION COMPETITION POLICY
}

\author{
SUMMARY
}

The aim of this paper is to present legal and economic aspects of granting state aid for research, development and innovation activities of enterprises in the European Union. The principles on acceptability of state aid in the light of the EU competition policy were discussed. The analysis involved the value, structure and trends in aid granted for mentioned purpose in Member States. Another issue concerned the lack of correlation between the value of aid granted for research and development activity and results achieved in the EU Member States in the field of innovation. The author focused also on the number of decisions taken by the European Commission regarding particular objectives, programs and Member States in which the aid for research, development and innovation was implemented. The theoretical information were derived from selected analytical and strategic elaborations, documents and reports. The empirical data gathered mainly from Directorate General for Competition of the European Commission and from the Eurostat base.

Keywords: state aid, R\&D\&I, competition policy, European Union

JEL Classification: D6, F30, F36, G18, H50

* Krzysztof Rutkiewicz, Wrocław University of Environmental and Life Sciences, Faculty of Life Sciences and Technology, Institute of Economics and Social Sciences, pl. Grunwaldzki 24a, 50-363 Wrocław, phone: +48 713201 794, e-mail: krzysztof.rutkiewicz@up.wroc.pl. 


\section{INTRODUCTION}

Promotion of research, development and innovation activity (R\&D\&I) of enterprises constitutes one of the crucial components of supporting competitiveness of the European Union (EU) and is a guarantee for its sustainable economic growth. Therefore, in the "Europe 2020" strategy, financing of R\&D\&I in EU was prioritized ${ }^{1}$. At the same time, it was emphasized that aid granted by Member States can become an effective instrument of promoting private investment in R\&D\&I, leading to elimination of already existing market imperfections.

According to neoclassical economic theory, the most appropriate stimulus of innovation is competition. Nevertheless, market failure in the field of allocation of resources, unequal distribution of income between the members of society, as well as the need for regulation of the economy, justify state intervention in the market ${ }^{2}$. Similarly, J.M. Keynes, paying attention to insufficient effective demand, unemployment and market instability, claimed that active government intervention would provide increased efficiency of economic system ${ }^{3}$.

From the point of view of welfare economics, in the conditions of perfect competition, the maximum economic satisfaction (Pareto-optimality) is enjoyed when it is not possible to improve one's situation without worsening it for somebody else ${ }^{4}$. Therefore, the market should feature efficiency of production $^{5}$, structure ${ }^{6}$ and exchange ${ }^{7}$ of produced goods. Nowadays, a significant role is played by dynamic efficiency, embodied in technological progress,

${ }^{1}$ European Commission, Europe 2020. A strategy for smart, sustainable and inclusive growth, $\operatorname{COM(2010)} 2020$ final, , Brussels 2010, p. 11.

${ }^{2}$ G. Mankiw, M.P. Taylor, Economics, Thomson Learning, London 2006, p. 5.

3 J. Keynes, The General Theory of Employment, Interest and Money, London 1967, p. 23; C. Kaupa, The More Economic Approach - a Reform based on Ideology?, „European State Aid Law Quarterly", No. 3/2009, p. 312, 317; M. Kąkol, Uzasadnienie ekonomiczne wspierania przedsiebiorstw ze środków publicznych - ocena efektywności gospodarczej, [in:] M. Krasnodębska-Tomkiel (ed.), Zmiany w polityce konkurencji na przestrzeni dwóch ostatnich dekad, UOKiK, Warszawa 2010, p. 343-345.

${ }^{4}$ J.E. Stiglitz, Ekonomia sektora publicznego, PWN, Warszawa 2004, p. 69.

5 Then economy is found on the curve of productive capabilities, producing maximum amount of one good at a given size of production of other goods.

6 The needs of individuals are fulfilled.

${ }^{7}$ Irrespective of what products are manufactured they reach the consumers who value them most. 
which creates social welfare and accelerates economic growth over a longer period by introduction of innovative processes and products 8 .

The most commonly indicated premises, regarding the necessity of granting state aid for R\&D\&I, connected with addressing market failures, include:

1. Positive external effects. Although transfer of knowledge implicates social benefits, their return rate can appear to be not attractive for a private investor, who will not be interested in realization of research projects without a suitable state intervention.

2. Public good, in the form of transfer of knowledge used by the others. A part of that knowledge can be protected by a patent, which allows the inventor to generate higher profits.

3. Information failures and asymmetries, translated into private investors` reluctance or lack of interest in funding high - value research projects at inadequate allocation of human resources.

4. The lack of mutual coordination of activities between entrepreneurs, as well as the problems involving the development of network with particular partners.

State aid, as a stimulator of investment in R\&D\&I, should encourage private entrepreneurs to undertake activities within that field, but it can sometimes be an instrument of protectionism. Inappropriately granted aid petrifies ineffective market structures and delays liquidation of unprofitable enterprises. It results in distortions in competition and trade, as well as in economic slowdown. Due to enhancing its market power a beneficiary can apply exclusionary practices or reduce any actions aiming at increasing innovation.

The purpose of this paper is to present legal and economic aspects of granting state aid for R\&D\&I of enterprises in the view of the EU competition policy. The verified hypothesis is a claim that Member States reckoned among innovation leaders (in comparison with other UE-27 countries) do not grant aid for R\&D\&I of the highest value. This article presents theoretical information derived from selected analytical and strategic elaborations, documents, reports as well as empirical data mainly from Directorate General for Competition - the European Commission and from the Eurostat base.

${ }^{8}$ L. Peeperkorn, Dynamic Welfare Analysis of Market Power, [in:] J. Faull, A. Nickpay (eds), The EC Law of Competition, Oxford University Press 1999, p. 39. 


\section{THE RULES FOR ADMISSIBILITY OF GRANTING STATE AID FOR R\&D\&I IN THE EU}

The principles concerning state aid for R\&D\&I were established in 2006 . These rules are applicable for all sectors, including those dependent on particular competition rules e.g. in the sectors of agriculture, fisheries, transport etc.

In accordance with Article 179 of the Treaty on the Functioning of the European Union (TFEU) the EU ought to enhance its scientific and technological base within the European framework in the realm of research in which knowledge is freely exchangeable as well as is conducive for international competitiveness $^{10}$. Consequently, in the year 2002 the European Council has approved the so called Barcelona target depending on the increase in expenditure on R\&D\&I to the level of 3\% of GDP. It was determined that two-thirds of new investments would be conducted by the private sector. According to the guidelines of the European Commission (hereafter: Commission) in order to achieve such a target it is required to reach $8 \%$ of the average annual rate of investment growth in R\&D\&I, with state expenditure increasing at the rate of $6 \%$, and private expenditure at the rate of $9 \%{ }^{11}$.

Granting state aid for R\&D\&I is acceptable based on Article 107(3)(b) of TFEU on condition that:

1. it concerns a project which is clearly defined in respect of the realization of its conditions;

2. it is conducive for the welfare of the whole EU, and the conducted research is pioneering;

3. it is connected with a high risk in the context of profitability and feasibility of the project;

4. the target, scope and dimension of the planned investment shall be of significant quality.

According to the quoted framework rules the following aspects of state aid are compatible with the UE market:

1. for R\&D\&I projects,

2. for technical feasibility studies,

3. to cover costs of industrial property rights for SMEs,

9 Community framework for state aid for research and development and innovation, „Official Journal of the EU”, C 323, 30.12.2006.

${ }^{10}$ Consolidated version of the Treaty on the Functioning of the European Union, "Official Journal of the EU”, C 115, 9.5.2008, p. 128.

${ }^{11}$ European Commission, Investing in research: an action plan for Europe, Brussels 2003, p. 3. 
4. for young innovative enterprises,

5. for process and organizational innovations in services,

6. for innovation advisory services and for innovation support services,

7. for temporal employment of highly qualified staff,

8. for innovation clusters.

Undertaking R\&D\&I actions should concern the process combining knowledge and technology with an opportunity for applying new products, services and business processes in practice. The degree of risk resulting from their unique quality is a premise justifying admissibility of aid for R\&D\&I. It is reflected in a higher tendency on the part of enterprises to invest, if research results allow them to make substantial commercial profits.

The UE regulations state it clearly that the closer R\&D\&I is to the market, the more possible it is that granting aid will result in competition distortion. Consequently, the Commission while defining the degree of closeness of market research distinguishes:

1. basic research, i.e. experimental or theoretical works aimed at acquiring new knowledge about phenomena and observable facts without focusing them on practical application or usage;

2. industrial research, i.e. planned or critical research aimed at acquiring new knowledge and skills for elaborating products, processes and services along with significant improvements of already existing products;

3. experimental development works aimed at acquiring, combining, forming and using currently available knowledge and skills with the purpose of planning and elaborating prototypes and pilot projects which can be commercially applicable.

\section{THE VALUE AND STRUCTURE OF STATE AID IN THE EU-27}

The total value of state aid granted in the EU-27 countries in the years 2004-2010 amounted to 1466.2 bln EUR, i.e. $1.8 \%$ of the EU-27 GDP per year (table 1). Out of this amount 949.9 bln EUR (1.2\% of the UE-27 GDP) constituted aid allotted to fight the financial crisis. Taking no anti-crisis measures into consideration, in the years 2004-2010 the EU-27 Member States spent 516.3 bln EUR (0.6\% of the EU-27 GDP). The value of aid which was granted to industry and services (395.3 bln EUR, 0.5\% of EU-27 GDP) constituted $77 \%$ of its total amount in the Community. The remaining $23 \%$ of aid was equivalent to the amount of support in the sectors of agriculture, forestry, fisheries, aquaculture and transport. 
Table 1. Value, structure and allocation of state aid in EU-27 in years 2004-2010

\begin{tabular}{|c|c|c|c|}
\hline ALLOCATION OF AID & $\begin{array}{c}\text { VALUE } \\
\text { (IN BLN EUR) }\end{array}$ & $\begin{array}{l}\text { SHARE } \\
\text { (IN \%) }\end{array}$ & $\begin{array}{c}\text { GDP EU-27 } \\
\text { (IN \% PER YEAR) }\end{array}$ \\
\hline A) INDUSTRY AND SERVICES, including: & 395.3 & (76.6) 100.0 & 0.48 \\
\hline 1. Horizontal aid, including: & 322.8 & (62.5) 81.7 & 0.39 \\
\hline - Environmental protection \& energy saving & 96.2 & (18.6) 24.3 & 0.12 \\
\hline - Regional development & 83.4 & (16.2) 21.1 & 0.10 \\
\hline - Research, development \& innovation & 57.5 & (11.1) 14.5 & 0.07 \\
\hline - Small and medium-sized enterprises & 36.2 & (7.0) 9.2 & 0.04 \\
\hline - Employment & 20.9 & (4.0) 5.3 & 0.03 \\
\hline - Culture and maintenance of national heritage & 10.4 & (2.0) 2.6 & 0.01 \\
\hline - Training employees & 5.9 & (1.1) 1.5 & 0.01 \\
\hline - Social aid to individual consumers & 5.0 & (1.0) 1.3 & 0.01 \\
\hline - Risk capital & 3.2 & (0.6) 0.8 & 0.00 \\
\hline - Promotion of export and internationalization & 3.2 & (0.6) 0.8 & 0.00 \\
\hline - Other horizontal purposes & 0.9 & (0.3) 0.3 & 0.00 \\
\hline 2. Sectoral aid, including: & 72.5 & (14.1) 18.3 & 0.09 \\
\hline - Coal-mining & 29.2 & (5.7) 7.4 & 0.04 \\
\hline - Financial services & 12.0 & (2.3) 3.0 & 0.01 \\
\hline - Restructuring of enterprises \& ship-building & 14.5 & (2.8) 3.7 & 0.02 \\
\hline - Other sectoral purposes & 16.8 & (3.3) 4.2 & 0.02 \\
\hline B) 1. AGRICULTURE AND FORESTRY* & 79.1 & $(15.3)$ & 0.10 \\
\hline B) 2. TRANSPORT & 41.9 & $(8.1)$ & 0.05 \\
\hline Total value of aid $(A+B)$ & 516.3 & $(100.0)$ & 0.63 \\
\hline C) Financial crisis measures & 949.9 & - & 1.16 \\
\hline Total state aid $(A+B+C)$ & 1466.2 & - & 1.79 \\
\hline
\end{tabular}

* including fisheries and aquaculture

Source: Own study based on:European Commission, Facts and figures on state aid in the EU Member States. Staff working paper, SEC(2011) 1487 final, Brussels 2011, p. 13, 61-64; European Commission, Scoreboard data on state aid expenditure, http://ec.europa.eu/competition/state_aid/studies_reports/expenditure.html (30.09.2013).

The structure analysis of the aid distributed between 2004 and 2010 indicates that $82 \%$ of the granted measures was of horizontal quality, the oth- 
er $18 \%$ was allotted to so called sensitive sectors (coal-mining, ship-building and steel industry) as well as to provide financial services.

Among the horizontal targets the most aid was granted for environmental protection and energy saving (96.2 bln EUR, i.e. 24.3\% of support for industry and services) which in the structure of state support, was assigned the prior significance by Sweden (86\%), Latvia (78\%), Holland (55\%), Austria (49\%), Finland (40\%), Estonia (39\%), Germany (38\%) and Great Britain (34\%). The value of that aid in the new Member EU-12 States ${ }^{12}$ amounted to $17.3 \%$, i.e. $7 \%$ less than its mean level in relation to the whole EU-27.

The second came aid for regional development (83.4 bln EUR, i.e. $21.1 \%$ of aid for A group in the period 2004-2010). It was dominant in the structure of the total aid granted to Greece (89\%), Lithuania (67\%), Romania (52\%), Slovakia (47\%), the Czech Republic (45\%), Bulgaria (41\%), France (34\%), Ireland and Italy (each 33\%).

In the third place was aid granted for R\&D\&I (57.5 bln EUR, 14.5\%). Funding for R\&D\&I constitutes a substantial part of state expenditure in Luxemburg (51\%), Belgium (43\%), Holland (37\%), Finland (31\%), Slovenia (30\%) and Spain (26\%). In the EU-12 States, on average, merely $10.8 \%$ of this aid was granted, i.e. $3.7 \%$ less than in the EU-27.

The three above mentioned purposes (environmental protection, regional development and R\&D\&I) consumed in total $59.9 \%$ of aid for industry and services. Hence, it can be stated that they reflect the main directions of horizontal allocation of state expenditure in the $\mathrm{EU}^{13}$.

The comparison of average share of respective types of horizontal aid in the structure of aid granted for industry and services in the years 20052007 and 2008-2010 (figure 1), clearly indicates that there was an increase in the level of support allotted to regional development (from 19\% to 23.5\%) and to R\&D\&I (from $13 \%$ to $15.5 \%$ ). Simultaneously there was a decrease in the average share of aid granted for environmental protection (from 26.1\% to $23.8 \%$ ), development of SMEs (from $10.1 \%$ to $4.8 \%$ ). Additionally, there was also a decrease in the share of the sectoral aid caused mainly by reduction in aid allotted to the coal-mining industry in Germany, Poland and Spain.

12 Bulgaria, Cyprus, Czech Republic, Estonia, Hungary, Latvia, Lithuania, Malta, Poland, Romania, Slovakia, Slovenia.

${ }^{13}$ The share of aid for the remaining horizontal targets in UE-27 (comprising the aid for employment, SMEs, social and cultural purposes, staff training, risk capital and promotion of export) was significantly lower and in the period 2004-2010 it amounted in total $21.5 \%$ of aid for industry and services. 
Figure 1. Tendencies in the structure of granting state aid in EU-27 in years 2005-2010 (in \%)

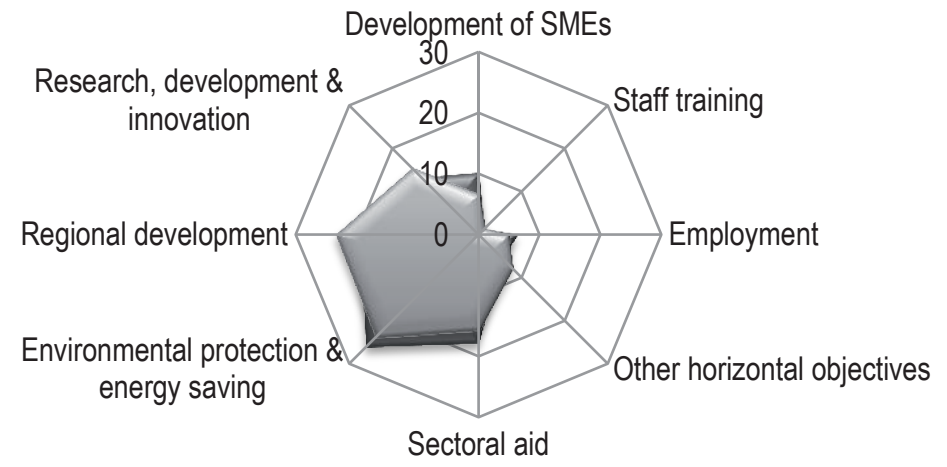

State aid objectives, 2005-2007

$\square$ State aid objectives, 2008-2010

Source: Own preparation based on European Commission, Scoreboard - data on state aid expenditure, http://ec.europa. eu/competition/state_aid/studies_reports/expenditure.html (30.09.2013).

\section{EXPENDITURE ON R\&D\&I IN THE EU-27 MEMBER STATES}

In the year 2010 the total value of gross expenditure on R\&D\&I in the EU-27 amounted to 245.7 bln EUR, i.e. 2\% of the EU-27 GDP (figure 2). Although the obtained value was 3.8\% higher than in the year 2009 and $43.5 \%$ higher than the level of expenditure in the year 2000, it still did not reach the target level of 3\%, which was stated in the "Europe 2020" strategy. Significant differences were observed between the EU-27 countries. Solely, Finland (3.87\%), Sweden (3.42\%) and Denmark (3.06\%) realized Barcelona target, allocating more than $3 \%$ of GDP to R\&D\&I. Finally, four other Member States - Germany (2.82\%), Austria (2.76\%), France (2.26\%) and Slovenia $(2.11 \%)$ - exceeded the Union mean value (2\%), and the other nine countries - did not reach the level of $1 \%$, taking into consideration the total state and private expenditure on R\&D\&I.

State aid granted for R\&D\&I in 2010 constituted relatively a slight part (10.9 bln EUR, i.e. $0.08 \%$ GDP) of all financial measures in the EU-27 Member States (table 2). Nearly $55 \%$ of the total value of aid for R\&D\&I was granted by only three countries: Germany (2.9 bln EUR, 26\%), France (1.9 bln EUR, 17\%) Spain (1.2 bln EUR, 11\%). Thirteen Member States granted aid exceeding the mean level $(0.08 \%$ GDP) for EU-27: Slovenia (0.27\%), Belgium (0.22\%), Ireland (0.20\%), Austria (0.18\%), the Czech Republic (0.17\%), Finland (0.13\%), Holland (0.12\%), Spain (0.11\%), Germany, Denmark and Hungary (each $0.10 \%$ ) as well as France and Luxemburg (each 
0.09\%). In contrast, there were six other countries (Bulgaria, Cyprus, Greece, Estonia, Malta, Portugal), which granted aid worth less than $0.01 \%$ GDP for R\&D\&I.

Figure 2. Gross domestic expenditure for R\&D\&l in UE-27 in 2010 (\% of GDP)

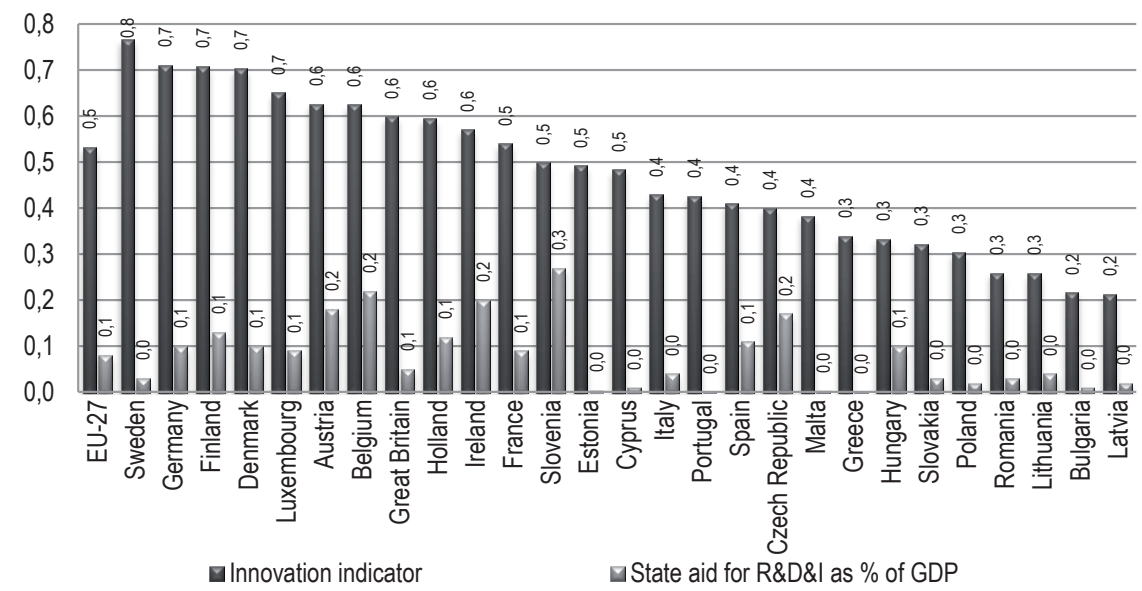

Source: Own preparation based on Eurostat, http://epp.eurostat.ec.europa.eu (30.09.2013).

In 2010 the amount of 1,1 bln EUR was spent within the frames of aid for R\&D\&I under the General Block Exemption Regulation ${ }^{14}$. Countries which benefited the most from it were Germany (259 mln EUR), Spain (175 mln EUR), Italy (152 mln EUR) and Belgium (121 mln EUR). The EU-27 Member States focused mainly on four aspects of support including: experimental development works (428 mln EUR), industrial research (312 mln EUR), technical feasibility studies (65 mln EUR) and covering the costs of industrial property rights for SMEs (53 mln EUR).

State aid for R\&D\&I in the EU-27 was granted in the form of 420 measures, out of which 137 constituted block exemptions in 2010 . The Commission approved six large programs, which constituted $25 \%$ of all expenses. Taking into account 13 other programs, in total, the aid of 50\% was granted for R\&D\&I in the EU-27. The States which acted as a beneficiary for the programs of the highest budget were as follows: France for 5 of them; Germany, Spain and Italy each for 3; Great Britain - for 2; Austria, Belgium and Finland each for 1.

${ }^{14}$ Commission Regulation (EC) No 800/2008 of 6.8.2008 declaring certain categories of aid compatible with the common market in application of Article 87 and 88 of the Treaty, Official Journal of the EU, L 214, 9.8.2008. 
Table 2. Value, structure and share in GDP of national state aid for R\&D\&I in UE-27 in 2010

\begin{tabular}{|c|c|c|c|c|c|c|c|}
\hline StATE & $\begin{array}{c}\text { VALUE } \\
\text { (MLN EU- } \\
\text { RO) }\end{array}$ & $\begin{array}{l}\text { SHARE } \\
(\text { IN \%) }\end{array}$ & $\begin{array}{c}\text { As } \% \\
\text { OF GDP }\end{array}$ & StATE & $\begin{array}{l}\text { VALUE } \\
\text { (MLN } \\
\text { EURO) }\end{array}$ & $\begin{array}{l}\text { SHARE } \\
(\text { IN \%) }\end{array}$ & $\begin{array}{c}\text { As } \% \\
\text { OF GDP }\end{array}$ \\
\hline EU-27 & 10920.4 & 100.0 & 0.08 & 14. Hungary & 99.0 & 0.9 & 0.10 \\
\hline 1. Germany & 2869.0 & 26.3 & 0.10 & 15. Slovenia & 96.9 & 0.9 & 0.27 \\
\hline 2. France & 1873.9 & 17.1 & 0.09 & 16. Poland & 70.3 & 0.6 & 0.02 \\
\hline 3. Spain & 1246.7 & 11.4 & 0.11 & 17. Portugal & 50.0 & 0.5 & 0.0003 \\
\hline 4. Great Britain & 831.0 & 7.6 & 0.05 & 18. Luxemburg & 38.0 & 0.4 & 0.09 \\
\hline 5. Belgium & 813.0 & 7.4 & 0.22 & 19. Romania & 31.9 & 0.3 & 0.03 \\
\hline 6. Holland & 703.0 & 6.4 & 0.12 & 20. Slovakia & 18.1 & 0.2 & 0.03 \\
\hline 7. Italy & 579.2 & 5.3 & 0.04 & 21. Lithuania & 11.0 & 0.1 & 0.04 \\
\hline 8. Austria & 521.8 & 4.8 & 0.18 & 22. Latvia & 4.3 & 0.04 & 0.02 \\
\hline 9. Czech Republic & 252.1 & 2.3 & 0.17 & 23. Bulgaria & 2.2 & 0.02 & 0.01 \\
\hline 10. Finland & 239.7 & 2.2 & 0.13 & 24. Cyprus & 1.8 & 0.02 & 0.01 \\
\hline 11. Ireland & 237.0 & 2.2 & 0.20 & 25. Greece & 1.5 & 0.01 & 0.001 \\
\hline 12. Denmark & 224.3 & 2.1 & 0.10 & 26. Estonia & 0.6 & 0.005 & 0.004 \\
\hline 13. Sweden & 103.9 & 1.0 & 0.03 & 27. Malta & 0.2 & 0.002 & 0.003 \\
\hline
\end{tabular}

Source: Own preparation based on European Commission, Facts and figures on state aid in the EU Member States. Staff working paper, SEC(2011) 1487 final, Brussels 2011, p. 74-100.

In a long-term perspective there occurs a gradual increase of the aid value granted for R\&D\&I. In the years 2004-2010 the amount of measures granted for R\&D\&I increased from 5.7 bln EUR (0.05\% of the EU-27 GDP) in the year 2004 to 10.9 bln EUR (0.08\%) in 2010. In that period $46 \%$ of the total amount of 57.9 bln EUR for R\&D\&I was granted by two States: Germany (15.3 bln EUR, i.e. 26\%) and France (11.6 bln EUR, 20\%). In total, one third of the aid was granted by four states: Italy (5.6 bln EUR, 10\%), Spain and Great Britain (each of about 5.4 bln EUR, i.e. 9\% each) and Belgium (3.4 bln EUR, 6\%) $)^{15}$.

The most common instruments of financing R\&D\&I in 2010 were direct grants (80\%), next - privileged loans (11\%) as well as tax exemptions (9\%). The remaining instruments, among others, in the form of capital shares, tax postponements and guarantees were of less significance. Notably, France and

15 European Commission, Report on state aid contribution to Europe 2020 Strategy. Spring 2011 update, Brussels 2011, p. 17. 
Spain were granted altogether $70 \%$ of aid in the form of privileged loans, but in case of Belgium and Great Britain $85 \%$ of aid constituted tax exemptions ${ }^{16}$.

\section{STATE AID FOR R\&D\&I AND THE VALUE OF INNOVATION INDICATORS IN THE EU-27}

The comparison between the value of state aid allocated to R\&D\&I in the EU-27 Member States and the value of their innovation indicators proves there is not a direct correlation between these variables (figure 3 ). In the range of innovation, many factors lead to the final outcome and these, among others, include: the level of state and private expenditures for R\&D\&I, the degree of the youth education, the number of trademarks per $1 \mathrm{mln}$ of citizens, or access to broadband Internet. These aspects do not only affect the value of the innovation indicator in the respective EU-27 States, but also reveal various possibilities to support R\&D\&I, among which state aid is one of many available instruments ${ }^{17}$.

According to the results ranking in the range of innovation in the year 2010, the innovation leaders were such Member States as: Sweden, Germany, Finland and Denmark and their innovation indicators (ranged from 0 to 1 ) each time exceeded the level of 0.7. Subsequently, another group included the States regarded as innovation followers such as: Luxemburg, Austria, Belgium, Great Britain, Holland, Ireland, France, Slovenia, Estonia and Cyprus.

${ }^{16}$ The special role of subsidies can be justified both theoretically as well as empirically. Grants may in fact be available for entrepreneurs who do not have current financial problems and confirmed their efforts by reaching a high level of company effectiveness. On the other hand, tax exemptions disenthrall companies from financial obligations by reducing costs of economic activity.

17 The "indicator of innovation output" measures the extent to which ideas from innovative sectors are able to reach the market, providing better jobs and making the EU more competitive. The indicator was designed at the request of EU leaders to benchmark national innovation policies (European Commission, Commission launches new innovation indicator, http://europa.eu/rapid/press-release_IP-13-831_en.htm (30.09.2013)). 
Figure 3. National innovation indicator and level of state aid for R\&D\&l in EU-27 in 2010

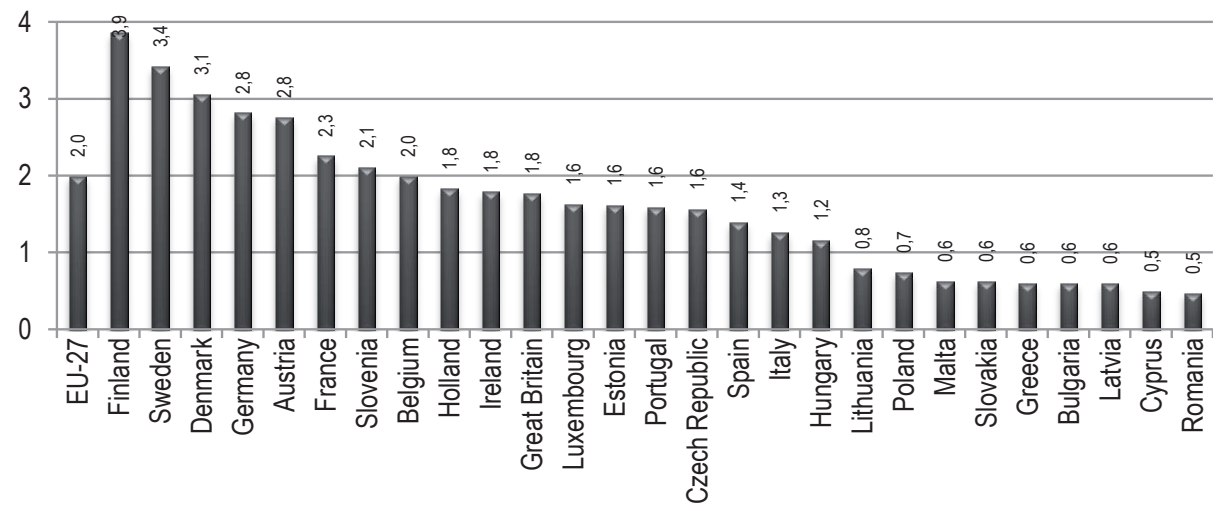

Source: Own preparation based on European Commission, Innovation Union Scoreboard 2011. Research and Innovation Union Scoreboard, Brussels 2012, p. 70.

Taking into account the relative value (calculated as a \% of GDP), most of the States granted aid exceeding the mean level (0.08) in the EU-27. The exceptions were Sweden, Great Britain, Estonia and Cyprus which contributed aid for R\&D\&I of less than half their mean level in the EU-27. In the remaining countries constituting the group of moderate and slight innovators (apart from the Czech Republic, Spain and Hungary) the value of aid granted for R\&D\&I was very low (below the mean level in the EU-27).

The research concerning Finland, which has led an effective innovation policy, revealed that aid for R\&D\&I had a positive impact on its economy $a^{18}{ }^{18}$ it encouraged private investments in R\&D\&I in a year after support was granted; it increased productivity of enterprises (mainly SMEs); it led to an increase in employment in the activity of R\&D\&I; it resulted in the higher, than the Finnish stocks, interest rate of the return of subsidies for R\&D\&I that amounted to $9 \%$.

\section{CONCLUSIONS}

The aid for R\&D\&I, which constitutes financial support for enterprises, is granted due to occurring market imperfections. It ought to be used as an

${ }^{18} \mathrm{~J}$. Ali-Yrkkö, Impact of public REंD financing on employment, „The Research Institute of the Finnish Economy Discussion Paper”, No. 980/2005, p. 7-10, 14; H. Piekkola, Public funding of $R E D D$ and growth: Firm-level evidence from Finland, „Economics of Innovation and New Technology”, Vol. 16, Issue 3/2007, p. 196, 207-208; O. Toivanen, Innovation and research policies: two case studies of REंD subsidies, „EIB Papers”, Vol. 11, No. 2/2006, p. 68. 
instrument leading to an increase in economic efficiency as well as to new innovative processes and products creating social welfare and economic growth in the longer period of time. Nevertheless, granting aid for R\&D\&I to insolvent companies leads to deterioration of their results, having negative effect on sales, profits, work efficiency, and intensity of R\&D\&I. Ineffectiveness of support for R\&D\&I can result from selectiveness consisting in the ranking of individual projects and lack of competitiveness between enterprises applying for funds ${ }^{19}$.

The research on state aid confirms that its effectiveness decreases with an increase in the value of aid. Furthermore, some enterprises (mainly SMEs) realize $R \& D$ projects without any aid (the effect of substitution). The same value of aid may be featured by a different effectiveness in the EU-27 States due to variations of the conditions on which it is granted ${ }^{20}$. Member States regarded as innovation leaders (e.g. Sweden, Finland or Denmark) do not necessarily grant aid of the highest value (in comparison to other EU-27 States) for R\&D\&I.

\section{BIBLIOGRAPHY}

Ali-Yrkkö J., Impact of public RED financing on employment, "The Research Institute of the Finnish Economy Discussion Paper", No. 980/2005.

Community framework for state aid for research and development and innovation, „Official Journal of the EU", C 323, 30.12.2006.

Consolidated version of the Treaty on the Functioning of the European Union, "Official Journal of the EU", C 115, 9.5.2008.

European Commission, Commission launches new innovation indicator, http://europa. eu/rapid/press-release_IP-13-831_en.htm (30.09.2013).

European Commission, Europe 2020. A strategy for smart, sustainable and inclusive growth, $\operatorname{COM}(2010) 2020$ final, Brussels 2010.

European Commission, Facts and figures on state aid in the EU Member States. Staff working paper, SEC(2011) 1487 final, Brussels 2011.

European Commission, Innovation Union Scoreboard 2011. Research and Innovation Union Scoreboard, Brussels 2012.

European Commission, Investing in research: an action plan for Europe, Brussels 2003. European Commission, Report on state aid contribution to Europe 2020 Strategy. Spring 2011 update, Brussels 2011.

19 T. Giebe, T. Grebe, E. Wolfstetter, How to allocate RED (and other) subsidies: An experimentally tested policy recommendation, „Research Policy”, Vol. 35/2006, p. 1261-1272.

20 R. Nitsche, P. Heidheus, Study on methods to analyse the impact of state aid on competition, „European Economy. Economic Papers”, No. 244/2006, p. 66. 
European Commission, Scoreboard - data on state aid expenditure, http://ec.europa.eu/ competition/state_aid/studies_reports/expenditure.html

(30.09.2013).

Giebe T., Grebe T., Wolfstetter E., How to allocate RED (and other) subsidies: An experimentally tested policy recommendation, „Research Policy”, Vol. 35/2006.

Kąkol M, Uzasadnienie ekonomiczne wspierania przedsiębiorstw ze śodków publicznych - ocena efektywności gospodarczej, [in:] M. Krasnodębska-Tomkiel (ed.), Zmiany w polityce konkurencji na przestrzeni dwóch ostatnich dekad, UOKiK, Warszawa 2010.

Kaupa C., The More Economic Approach - a Reform based on Ideology, „European State Aid Law Quarterly", No. 3/2009.

Keynes J., The General Theory of Employment, Interest and Money, London 1967.

Mankiw G., Taylor M.P., Economics, Thomson Learning, London 2006.

Nitsche R., Heidheus P., Study on methods to analyse the impact of state aid on competition, "European Economy. Economic Papers", No. 244/2006.

Peeperkorn L., Dynamic Welfare Analysis of Market Power, [in:] J. Faull, A. Nickpay (eds), The EC Law of Competition, Oxford University Press 1999.

Piekkola H., Public funding of RED and growth: Firm-level evidence from Finland, „Economics of Innovation and New Technology”, Vol. 16, Issue 3/2007, http:// dx.doi.org/10.1080/10438590600661897.

Stiglitz J.E., Ekonomia sektora publicznego, PWN, Warszawa 2004.

Toivanen O., Innovation and research policies: two case studies of $R E D D$ subsidies, „EIB Papers", Vol. 11, No. 2/2006.

Commission Regulation (EC) No 800/2008 of 6.8.2008 declaring certain categories of aid compatible with the common market in application of Article 87 and 88 of the Treaty, Official Journal of the EU, L 214, 9.8.2008.

Eurostat, http://epp.eurostat.ec.europa.eu (30.09.2013). 